\title{
SISTEM CERDAS MENDETEKSI KUALITAS GULA MERAH MENGGUNAKAN METODE NEAREST MEAN CLASSIFIER (NMC)
}

\author{
Bayu Rianto ${ }^{1}$, Azhari $^{2}$ \\ 1,2Prodi Sistem Informasi, Fakultas Teknik \& Ilmu Komputer, Universitas Islam Indragiri, Tembilahan \\ Email: rianto.bayu91@gmail.com (korespondensi)
}

\begin{abstract}
The development and utilization of digital images has developed rapidly. At present, digital image processing capabilities and techniques make it possible to be used more effectively and efficiently in identifying quality classes of brown sugar. One of them is the concept of Smart Systems with the use of Matlap-based applications so that public recognition of the importance of selecting good quality brown sugar can be a little more efficient. Digital image processing capabilities are supported by the concept of pattern recognition and classification, it is expected that the quality classification of brown sugar based on RGB color variables (Red, Green, Blue) and texture variables (energy, contrast, correlation and homogeneity) with the help of computers can be realized. To get a solution of the problem of classification and determine the accuracy of the classification of the quality of brown sugar into a certain class, then we need a method that is able to classify the quality of brown sugar brown sugar into class $A$ (very good), class B (good) and class C (not good). The method is expected to also be able to handle the problem of the accuracy of the classification of brown sugar into certain quality classes according to the actual state of brown sugar.
\end{abstract}

Keywords: Nearest Mean Classifier (NMC), Smart System, Brown Sugar.

\begin{abstract}
Abstrak
Perkembangan dan pemanfaatan citra digital telah berkembang pesat. Saat ini, kemampuan dan teknik pengolah citra digital memungkinkan untuk digunakan lebih efektif dan efisien dalam mengidentifikasi kelas kualitas gula merah. Salah satunya adalah konsep Sistem Cerdas Dengan Pemanfaatan aplikasi berbasis Matlap sehigga pengenalan masyarakat akan pentingnya pemilihan kualitas gula merah yang baik bisa sedikit lebih efesien. Kemampuan pengolah citra digital didukung oleh konsep pengenalan dan klasifikasi pola, maka diharapkan klasifikasi kualitas gula merah berdasarkan variabel warna RGB (Red, Green, Blue) dan variabel tekstur (energy, contrast, correlation dan homogeneity) dengan bantuan komputer dapat direalisasikan. Untuk mendapatkan solusi dari permasalah klasifikasi dan menentukan nilai keakuratan klasifikasi kualitas gula merah kedalam kelas tertentu, maka diperlukan suatu metode yang mampu melakukan klasifikasi kualitas Gula Merah Gula Merah kedalam kelas A (sangat baik), kelas B (baik) dan kelas C (kurang baik). Metode tersebut diharapkan juga dapat menangani masalah keakuratan klasifikasi gula merah kedalam kelas kualitas tertentu sesuai dengan keadaan gula merah yang sebenarnya.
\end{abstract}

Kata kunci: Nearest Mean Classifier (NMC), Sistem Cerdas, Gula Merah.

\section{PEndahuluan}

Sembilan bahan pokok atau sering disingkat sembako adalah kebutuhan pokok masyarakat yang terdiri atas berbagai bahanbahan makanan dan minuman. Semua masyarakat dari yang tingkat ekonominya rendah sampai tinggi pasti membutuhkan sembako untuk memenuhi kebutuhannya setiap hari. Oleh karena itu, sembako mempunyai peranan penting dalam kehidupan masyarakat sehingga mudah didapatkan di warung-warung kecil, pasar tradisional, swalayan sampai mall sekalipun.

Salah satu dari sembilan bahan pokok kebutuhan manusia adalah gula. Sebagai barang konsumsi, gula mempunyai peranan penting dalam sistem pangan manusia, selain sebagai penyedia rasa manis, gula menjadi pemasok kalori yang cukup penting.Gula merah adalah hasil olahan nira yang berbentuk padat dan berwarna coklat kemerahan sampai dengan coklat tua. Nira yang digunakan biasanya berasal dari 
tanaman kelapa, aren, lontar atau siwalan, dan tebu.

Gula merah dijadikan masyarakat sebagai bahan pokok dan penting dalam konsumsi gizi harian, sehingga kualitas gula merah itu sendiri sangat perlu untuk diperhatikan. Gula merah yang sering kita jumpai di pasar memiliki kualitas serta mutu yang berbeda-beda. Hal yang mempengaruhi kualitas gula merah tersebut terutama dari rasa dan penampilannya, yaitu bentuk, serta warna. Klasifikasi akan kualitas gula merah yang dilakukan dipasar selama ini dilakukan secara manual, yakni ditentukan dengan penglihatan (pengamatan) mata terhadap gula merah itu sendiri. Klasifikasi kualitas gula merah yang dilakukan secara manual tentu akan mengakibatkan kurang teliti dikarenakan keterbatasan visual, kelelahan, perbedaan persepsi masing-masing pengamat dan menimbulkan kesulitan dalam mengklasifikasikan kualitas gula merah tersebut, pada saat jumlahnya cukup banyak. Klasifikasi kualitas gula merah yang dilakukandi pasar selama ini juga belum menghasilkan nilai / tingkat keakuratan klasifikasi kedalam kelas kualitas tertentu.

Berdasarkan latar belakang yang telah di kemukakan di atas, dapat di rumuskan masalah sebagai berikut:(1) Kesulitan dalam mengklasifikasikan gula merah dalam jumlah besar secara akurat kedalam suatu kelas kualitas yang terdiri darikelas A (sangat baik), kelas B (baik) dan kelas C (kurang baik) berdasarkan variabel warna dan tekstur Gula Merah. (2) Untuk beberapa orang, biaya berkonsultasi kepada pakar atau dokter ahli tidak murah.(3)Terkadang sulit untuk menemui dokter atau pakar.

Tujuan yang ingin di capai adalah sebagai berikut: (1)Untuk memudahkan orang dalammencari informasi tentang pertumbuhan pada anak.(2) Belum adanya penerapan metodeNearest Mean Classifier (NMC) untuk menentukan kualitas gula merah. (3) Belumadanya nilai/tingkat keakuratan klasifikasim kualitas gula merah.

Manfaat dari penelitian ini adalah sebagai berikut: (1)Diharapkan hasil dari penelitian ini mampu mengklasifikasikan gula merah kedalam kualitas kelas A (sangat baik), kelas B (baik) dan kelas C (kurang baik) sesuai keadaan gula merah yang sebenarnya dan mampu memberikan tingkat keakuratan klasifikasi (2) Pembaca dapat lebih mengetahui dan memahami tentang metode Nearest Mean Calsscifier (NMC) yang diaplikasikan untuk klasifikasi menentukan Kualitas Gula Merah.

\section{TINJAUAN PUSTAKA}

Suatu sistem pada dasarnya adalah sekelompok unsur yang erat hubungannya satu dengan yang lain, yang berfungsi bersama- sama untuk mencapai tujuan tertentu (Sutabri, 2012). sedangkan menurut, Kusrini (2007). Sistem adalah sebuah tatanan yang terdiri atas sejumlah komponen fungsional (dengan tugas/ fungsi khusus) yang saling berhubungan dan secara bersama-sama bertujuan untuk memenuhi suatu proses/ pekerjaan tertentu [1]. Cabang terpenting dalam dunia komputer adalah Kecerdasan Buatan atau Sistem cerdas atau Intelegensi Buatan atau Artificial inteligence. . Kecerdasan Buatan adalah ilmu rekayasa yang membuat suatu mesin mempunyai intelegensi tertentu khususnya program komputer yang "cerdas". Beberapa macam bidang yang menggunakan kecerdasan buatan antara lain sistem pakar, permainan komputer (games), logika Fuzzy, jaringan syaraf tiruan dan robotika. Himpunan Fuzzy Dalam masalah sehari-hari kita biasa berhubungan dengan hal-hal yang tidak cukup untuk dinyatakan dalam basis ya atau tidak saja, jadi bisa dikatakan bahwa adalah lebih baik bila suatu hal dinyatakan dengan suatu nilai di antara ya atau tidak. mengemukakan suatu teori himpunan dimana suatu hal dapat memiliki derajat keanggotaan yang terletak pada suatu nilainilai yang kontinu, lain dengan himpunan biasa yang hanya memiliki derajat keanggotaan 0 atau 1 saja[2] .

Gula merah merupakan salah satu bahan pangan yang dibuat dari nira palma termasuk kelapa dan aren. Permintaan gula merah semakin meningkat karena bertambahnya kesadaran masyarakat untuk menjaga kesehatan dengan mengurangi konsumsi gula pasir dan menggantikannya dengan gula merah. Gula merah mempunyai kelebihan antara lain warna kecoklatan dan aroma yang khas serta mempunyai nilai indeks glikemik yang rendah dibandingkan gula pasir yaitu 35 (Pertiwi, 2015), sehingga baik dikonsumsi oleh penderita diabetes atau masyarakat yang ingin menjaga kesehatan. Gula merah diproduksi oleh pengrajin gula merah dengan kapasitas produksi 10-20 kg/hari (Nawansih, 2013). Keterbatasan pengetahuan dan rendahnya tingkat pendidikan pengrajin gula menyebabkan sanitasi proses mulai dari penyadapan sampai pengemasan produk kurang diperhatikan. Demikian juga dalam menambahkan bahan pengawet seringkali berlebihan serta ada peluang ditambahkan 
bahan campuran untuk meningkatkan rendemen[3]

Nearest mean classifier (NMC) adalah sebuah teknik untuk melakukan klasifikasi (Bhavsar 2017). NMC sebagai sebuah pemilah menggunakan kemiripan antar pola untuk melakukan klasifikasi. Untuk setiap kelas, NMC menghitung rata-rata kelas (centroid) dari sampel data. Kemiripan diperoleh melalui perhitungan jarak Euclidean antara pola yang tidak diketahui dengan centroid dari sampel data. NMC mengklasifikasikan sebarang pola yang tidak diketahui ke kelas dengan centroid yang terdekat dengan pola yang akan dikenali. NMC telah berhasil diterapkan pada masalah klasifikasi dan menunjukkan hasil yang baik. Nearest Mean Classifier adalah pemilah linier sederhana untuk mengklasifikasikan sebuah objek yang tidak diketahui ke dalam suatu kelas terdekat. Metode ini disebut juga Minimum Euclidean Distance Classifier. Metode inimudah dimengerti dan mudah diimplementasikan karena tidak membuat asumsi tentang distribusi data dalam ruang fitur. Setiap kelas (cluster) diwakili oleh rata-rata vektor fitur objek yang sekelas berdasarkan data training.Rata-rata vektor fitur kelas (class mean) menjadi titik pusat kelas atau istilah lainnya adalah cluster centroid. Selanjutnya klasifikasi didasarkan atas jarak terdekat vektor fitur objek dengan vektor fitur class mean[4].

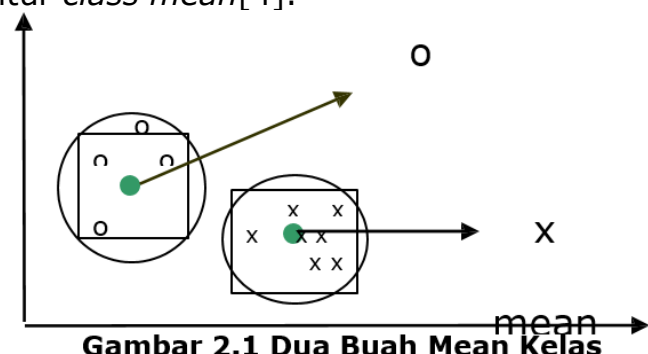

Mean kelas (class mean) pada masingmasing kelas dihitung berdasarkan nilai ratarata fitur objek yang berada pada kelas yang sama. Aturan klasifikasi pada metode in dapat dijelaskan sebagai berikut dibawah ini.

Jika diberikan dua Gula Merah kelas $\mathrm{w}_{1}$ dan $w_{2}$. Vektor dituliskan sebagai $\left\{x_{1}, \ldots, x_{n}\right\}$, jika $\bar{x}_{(\mathrm{i})}$ adalah mean kelas $\mathrm{w}_{\mathrm{i}}$ maka untuk objek baru $z$ direpresentasikan dalam ruang sebagai $z_{x}$ maka aturan klasifikasi didefenisikan sebagai berikut :

a. Klasifikasikan z kedalam kelas $w_{1}$ jika dan hanya jika $\mathrm{D}^{2}\left(\mathrm{z}, \bar{x}_{(1)}\right)<\mathrm{D} 2(\mathrm{z}, \bar{x}$ (2))

b. Klasifikasikan z kedalam kelas $w_{2}$ jika dan hanya jika $\mathrm{D}^{2}\left(\mathrm{z}, \bar{x}_{(2)}\right)<\mathrm{D} 2\left(\mathrm{z}, \bar{x}_{(1)}\right)$
Algoritma pemilah kelas terdekat adalah sebagai berikut

a. Tentukan mean vektor fitur (m) untuk setiap kelas.

b. Untuk setiap objek, hitung jaraknya (norma vektor) ke setiap mean $(\mathrm{m})$

c. Objek di klasifikasikan ke kelas yang jaraknya minimum (terkecil).

Context digram merupakan alat bantu perancangan sistem secara global yang memperlihatkan hubungan antara entityentity dari aliran sistem informasi utama dalam sebuah sistem. Context digram memperlihatkan input, output, dan hubungannya dengan proses serta batasan sistem. Context diagram menggambarkan sistem secara logika[5].

[6]Zefriyenni dan Santoso (2015) Context Diagram adalah gambaran umum tentang suatu sistem yang terdapat didalam suatu organisasi yang memperlihatkan batasan (boundary) sistem, adanya interaksi antara eksternal entity dengan suatu sistem dan informasi secara umum mengalir diantara entity dan sistem. Context Diagram merupakan alat bantu yang digunakan dalam menganalisa sistem yang akan dikembangkan. Simbol- simbol yang digunakan di dalam Context Diagram hampir sama dengan simbol-simbol yang ada pada DFD, hanya saja pada Context Diagram tidak terdapat simbol file (Darmanta, 2017). Berikut simbol-simbol dari Contex Diagram :

Tabel 1 Simbol-simbol dari Context Diagram (CD)

\begin{tabular}{|c|c|c|}
\hline No & Gambar & Keterangan \\
\hline 1 & & $\begin{array}{l}\text { Kesatuan } \\
\text { Luar(EksternalEntity) } \\
\text { Merupakan kesatuan luar } \\
\text { sistem yang dapat berupa } \\
\text { orang. organisasi atau sistem } \\
\text { lainya yang berada diluar } \\
\text { lingkungan luarnya yang } \\
\text { akan memberikan input atau } \\
\text { menerima output sistem. }\end{array}$ \\
\hline 2 & & $\begin{array}{l}\text { Proses (Process) = Kegiatan } \\
\text { atau kerja yang dilakukan } \\
\text { oleh, mesin atau komputer } \\
\text { dari suatu arus data yang } \\
\text { masuk ke dalam proses untuk } \\
\text { dihasilkan arus data yang } \\
\text { akan keluar dari proses }\end{array}$ \\
\hline 3 & & $\begin{array}{l}\text { Arus Data (Data Flow) = } \\
\text { Arus data mengalir diantara } \\
\text { proses, simpanan data dan } \\
\text { kesatuan. Arus data ini } \\
\text { menunjukan arus data dari } \\
\text { yang masuk ke dalam proses } \\
\text { sistem }\end{array}$ \\
\hline
\end{tabular}

Data Flow Diagram (DFD) disebut juga dengan Diagram Arus Data (DAD). DFD adalah: suatu model logika data atau proses yang dibuat untuk menggambarkan: darimana asal data, dan kemana tujuan data yang keluar dari sistem, dimana data 
disimpan, proses apa yang menghasilkan data tersebut, dan interaksi antara data yang tersimpan, dan proses yang dikenakan pada data tersebut[7].

[6]Data Flow Diagram mempunyai 4 simbol dalam masing-masing versi. Diantaranya :

Tabel 2 Simbol Data Flow Diagram(DFD)

\begin{tabular}{|c|c|c|}
\hline No & Gambar & Keterangan \\
\hline 1 & & $\begin{array}{l}\text { Kesatuan Luar(EksternalEntity) = } \\
\text { Merupakan kesatuan luar sistem } \\
\text { yang dapat berupa orang. } \\
\text { organisasi atau sistem lainya yang } \\
\text { berada diluar lingkungan luamya } \\
\text { yang akan memberikan input atau } \\
\text { menerima output sistem. }\end{array}$ \\
\hline 2 & & $\begin{array}{l}\text { Proses. Simbol ini digunakan } \\
\text { untuk melakukan proses } \\
\text { pengolahan data, yang } \\
\text { menunjukkan suatu kegiatan } \\
\text { yang mengubah aliran data yang } \\
\text { masuk menjadi keluaran. }\end{array}$ \\
\hline 3 & & $\begin{array}{l}\text { Penyimpanan Data/Data Store } \\
\text { menupakan tempat penyimpanan } \\
\text { dokumen-dokumen atau file-file } \\
\text { yang dibutuhkan. }\end{array}$ \\
\hline 4 & & $\begin{array}{l}\text { Aliran Data. Menunjukkan arus } \\
\text { data dalam proses. }\end{array}$ \\
\hline
\end{tabular}

Matlab merupakan bahasa pemrograman dengan kemampuan tinggi dalam bidang komputasi. Matlab merupakan paket perangkat lunak yang memampukan anda untuk melakukan komputasi matematik, menganalisa data, mengembangkan algoritma, melakukan simulasi dan pemodelan, dan menghaslkan tampilan grafik dan antarmuka grafikal [8]. Matlab adalah bahasa pemograman level tinggi yang dikhususkan untuk komputasiteknik. Matlab mengintegrasikan kemampuanuntuk komputasi, visualisasi data danpemograman dalam sebuah sebuahlingkungan yang interaktif dan mudahdigunakan. Matlab menggunakan konseparray atau matriks yang membantu menganalisa data, mengembangka nalgoritma, membuat model dan aplikasi.Matlab muncul di dunia bahasa pemograman yang cenderung di kuasai oleh bahasa yang telah mapan. Matlab hadir tidak dengan fungsi dan karakteristik yang ditawarkan bahasa pemograman lain tetapi dikembangkan sebagai bahasa pemogramansekaligus alat visualisasi data

,yang menawarkan banyak kemampuan untuk menyelesaikan berbagai kasus yang berhubungan langsung dengan disiplin keilmuan Matematika, seperti bidang rekayasa teknik, fisika statistika, komputasi danmodeling. Matlab dibangun dari bahasainduknya yaitu bahasa $C$, namun tidak dapat dikatakan serbagai varian terhadap bahasa C,karena dalam syntak maupun cara kerjanya sama sekali berbeda dengan C. amun denganhubungan langsung terhadap C, matlab memiliki kelebihan dari bahasa C, bahkanmampu berjalan pada semua platform sistemoperasi tanpa mengalami perubahan sintaksama sekali[9].

Citra digital merupakan image dimana $f(x, y)$ yang telah didigitalisasikan (dibentuk menjadi diskrit) baik koordinat spasialnya atau tingkat intensitasnya (Bhat 2014). Citra yang ada didigitalisasi agar mudah diolah dan disimpan dalam media penyimpanan seperti memori computer, hard disk atau media lain. Dalam penelitian ini prediksi citra kopra dilakukan pada citra warna 24 bit dengan format Jpeg (jpg) dengan ukuran $640 \times 480$ piksel. Setiap piksel menyatakan kombinasi komponen warna red, green dan blue (RGB). Model RGB adalah model warna 24 bit. Dalam model warna 24 bit masing-masing kanal warna $(R, G, B)$ memiliki 256 bin. Masingmasing komponen warna direpresentasikan dengan 8 binary digit. Delapan binary digit ini merepresentasikan angka intensitas pada piksel. Oleh karena itu terdapat sebanyak 28 $=$

256 derajat intensitas (0- 255) untuk masing- masing komponen warna. Citra model warna 24 bit dikenal juga dengan sebutan citra 16 juta warna, sebab citra model ini dapat memproduksi sebanyak 224 $=16.777 .216$ kombinasi warna. Setiap citra dalam model RGB, maka pada setiap kanal warna R (red), G (green) dan B (blue) memiliki histogram. Histogram adalah fungsi yang mendistribusikan jumlah piksel yang ada pada suatu citra untuk setiap level intensitas. Absisnya yang merupakan sumbu $x$ adalah tingkat intensitas, dan ordinatnya yang merupakan sumbu y adalah frekuensi kemunculan atau banyaknya piksel dengan nilai intensitas tertentu[4].

Objek yang ditangkap melalui kamera digital disimpan dalam bentuk digital. Intensitas RGB pada masing-masing piksel yang membentuk citra dapat diilustrasikan sebagaimana matriks di bawah ini: 


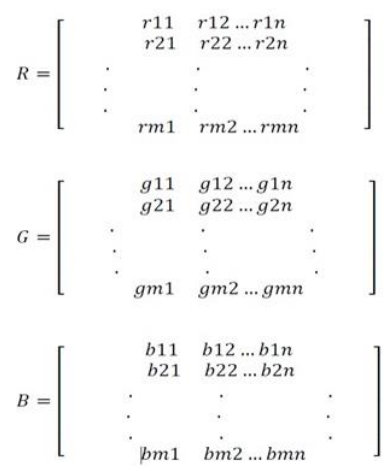

Tujuan dilakukannya pengolahan citra pada klasifikasi pola adalah untuk memperbaiki mutu citra tersebut sehingga mudah diproses oleh komputer. Pengolahan citra merupakan langkah praproses (preprocessing) sebelum proses klasifikasi dilakukan dan termasuk didalamnya background subtraction (Kumar and Yadav 2017). Pengolahan citra akan mentransformasi citra yang asalnya kurang baik menjadi citra keluaran yang lebih baik. Dengan demikian, input nya merupakan citra dan output nya citra pula, hanya saja citra keluaran akan lebih berkualitas dibandingkan citra asal[4].

Data Mining menurut David Hand, Heikki Mannaila, dan Padhraic Smyth dari MIT adalah analisa terhadap data (biasanya data yangberukuran besar) untuk menemukan hubunganyang jelas serta menyimpulkannya yang belum diketahui sebelumnya tersebut[10].

Klasifikasi adalah proses pengelompokan objek ke dalam kategori tertentu berdasarkan fiturnya. Algoritma klasifikasi adalah sebuah fungsi yangmemetakan objek ke salah satu label kelas tertentu. Algoritma klasifikasi atau classifier digunakan untuk melakukan tugas klasifikasi. Klasifikasi bertujuan untuk menentukan kategori objek yang belum diketahui label kelasnya berdasarkan karakteristik yang dimiliki objek tersebut, untuk dikategorikan ke dalam salah satu label kelas tertentu yang telah didefinisikan sebelumnya. Dalam klasifikasi terdapat dua proses yang dilakukan yaitu dengan membangun classifier (model) untuk disimpan dalam memori dan selanjutnya dilakukan pengenalan, klasifikasi atau prediksi pada suatu objek untuk ditentukan kategorinya berdasarkan model yang telah disimpan dalam memori tersebut. Model dapat berbentuk aturan (rule), pohon keputusan, jaringan syaraf tiruan ataupun formula matematika[4].

Zefriyenni dan Santoso (2015) MySQL merupakan software RDBMS (server database) yang dapat mengelola database dengan cepat, dapat menampung data dengan jumlah yang besar, dapat diakses banyak user (multi-user) dan dapat melakukan suatu proses sikron atau bersamaan (multi-threaded) (Darmanta, 2017). Menurut MADCOMS (2016) "Xampp adalah sebuah paket kumpulan software yang terdiri dari Apache, MySQL, PhpMyAdmin, PHP, Perl, Filezilla, dan lain." Xampp berfungsi untuk memudahkan instalasi lingkungan PHP, di mana biasanya lingkungan pengembangan web memerlukan PHP, Apache, MySQL dan PhpMyAdmin[11].

\section{METODOLOGI PENELITIAN}

Pada penelitian ini, data yang akan di inputkan adalah data berupa citra Gula Merah dalam jumlah yang ditentukan sebagai data citra pelatihan dan juga nantinya akan diinputkan citra yang belum diketahui kelasnya sebagai data pengujian.

Tabel 3. Data Citra Pelatihan

\begin{tabular}{|c|c|c|c|}
\hline No. & Kelas & Jumlah & $\begin{array}{c}\text { Contoh } \\
\text { Gambar }\end{array}$ \\
\hline 1 & Kelas A & 10 & \\
\hline 2 & Kelas B & 10 & \\
\hline 3 & Kelas C & 10 & \\
\hline & Total & 30 & \\
\hline
\end{tabular}

Citra yang akan menjadi data pelatihan berjumlah 30 Gula Merah yaitu terdiri dari 3 kelas kualitas, masing-masing kelas 10 citra.

Tabel 4. Data Citra Pengujian

\begin{tabular}{|c|c|c|c|}
\hline No. & Kelas & Jumlah & $\begin{array}{c}\text { Contoh } \\
\text { Gambar }\end{array}$ \\
\hline 1 & Kelas A & 5 & \\
\hline 2 & Kelas B & 5 & \\
\hline 3 & Kelas C & 5 & \\
\hline & Total & 15 & \\
\hline
\end{tabular}


Citra yang akan menjadi data pengujian berjumlah 15 Gula Merah yaitu terdiri dari 3 kelas kualitas, masing-masing kelas 5 citra Semua citra, baik citra latih ataupun citra uji terlebih dahulu akan dikonversi ke format BMP dan diubah resolusinya menjadi $640 x$ 480 piksel. Hal ini dilakukan untuk meringankan kinerja software.

\subsection{Proses Pembentukan Kelas}

Dalam pembentukan kelas kualitas Gula Merah, diperlukan karekteristik dari kelas kualitas Gula Merah itu sendiri yaitu dari segi warna dan tekstur. Seperti pada tabel 5 dibawah ini.

Tabel 5. Karakteristik Kelas Kualitas Gula MerahGula Merah

\begin{tabular}{|c|c|c|c|}
\hline No. & \begin{tabular}{|c|} 
Kelas \\
Kualitas
\end{tabular} & Warna & Tekstur \\
\hline 1 & Kelas A & RGB $0-255$ & APC $[\ldots]-[\ldots]$ \\
\hline 2 & Kelas B & RGB $0-255$ & APC $[\ldots .]-.[\ldots]$ \\
\hline 3 & Kelas C & RGB $0-255$ & $\mathrm{APC}[\ldots]-[\ldots]$ \\
\hline
\end{tabular}

Kelas A merupakan kelas untuk Gula Merah yang berkualitas Sangat baik, kelas B merupakan kelas Gula Merah yang berkualitas Baik dan kelas $\mathrm{C}$ yang merupakan kelas Gula Merah yang Kurang Baik. Tiap kelas kualitas dibedakan berdasarkan nilai fitur warna (red, green, blue) dan bentuk (area, perimeter dan compactness).

Setelah diketahui karakteristik kelas kualitas Gula Merah, maka proses pembentukan kelas bisa dilakukan. Proses pembentukan kelas diawali dengan melakukan ektraksi fitur citra latih. Tiap citra akan diekstrak untuk mendapatkan nilai red, green, blue dari variabel warna kemudian area, perimeter dan compactnessdari variabel tekstur. Setelah dilakukan proses ekstraksi fitur citra latih, hasilnya akan disimpan di dalam database vektor fitur citra pelatihan.

\subsection{Proses Perhitungan Jarak}

Proses ini diawali dengan pemanggilan citra uji (citra query) yang ingin dicari kelas kualitasnya. Kemudian citra query akan diekstrak untuk mendapatkan vektor fitur citra query, dapat dilihat pada tabel 6 dibawah ini.

Tabel 6. Vektor Fitur Citra Query

\begin{tabular}{|l|l|l|l|l|l|l|l|}
\hline \multirow{2}{*}{ Nama } & \multicolumn{2}{|l|}{ Warna } & \multicolumn{5}{|l|}{ Tekstur } \\
\cline { 2 - 7 } & Red & Green & Blue & Ene & Con & Corr & Hom \\
& & & & & & & \\
\hline Citra & RGB & RGB & RGB & GLCM & GLCM & GLCM & GLCM \\
Quer & {$[0]-$} & {$[0]-$} & {$[0]-$} & {$[\ldots]-$} & {$[\ldots]-$} & {$[\ldots]-$} & {$[\ldots]-$} \\
& {$[255]$} & {$[255]$} & {$[255]$} & {$[\ldots]$} & {$[\ldots]$} & {$[\ldots]$} & {$[\ldots]$} \\
\hline
\end{tabular}

Setelah didapatkan vektor fitur Red, Green dan Blue dari variabel warna kemudian energy, contrast, correlation dan homogeneity dari variabel tekstur. Perbandingan tersebut dapat dilakukan dengan cara menghitung jarak euclidean distance yang merupakan selisih nilai piksel antara 2 vektor tersebut. Adapun rumus euclidean distance ditunjukkan pada persamaan berikut ini:

Dist $(\mathrm{i}, \mathrm{k})=\sqrt{\sum_{\mathrm{i}=j_{j}\left(i_{j}-k_{j}\right)^{2}}^{2}}$

Dengan dist $(i, k)$ adalah jarak euclidean antara vektor $\mathrm{i}$ dan vektor $\mathrm{k}$

$$
\begin{aligned}
\mathrm{ij} & =\text { komponen ke } \mathrm{j} \text { dari vektor } \mathrm{i} \\
\mathrm{kj} & =\text { komponen ke } \mathrm{j} \text { dari vektor } \mathrm{k} \\
\mathrm{D} & \text { adalah jumlah komponen pada } \\
& \text { vektor } \mathrm{i} \text { dan vektor } \mathrm{k} .
\end{aligned}
$$

Dari hasil perhitunga jarak euclidean tersebut dapat ditentukan suatu citra query adalah mirip bila memiliki jarak yang paling dekat atau nilainya paling kecil.

Cotoh data:

Terdapat data klasifikasi kualitas Gula Merah ke dalam kelas Gula Merah yaitukelas A, B dan $C$ berdasarkan variabel warna RGB (Red Green Blue).

Tabel 7. Database Vektor Fitur Citra pelatih

\begin{tabular}{|c|c|c|c|}
\hline \multicolumn{3}{|c|}{ Warna } & \multirow{2}{*}{$\begin{array}{c}\text { Kelas Gula } \\
\text { Merah }\end{array}$} \\
\cline { 1 - 2 } Red & Green & Blue & KelasC \\
\hline 62 & 58 & 23 & Kelas C \\
\hline 63 & 50 & 28 & Kelas C \\
\hline 57 & 44 & 19 & Kelas B \\
\hline 58 & 42 & 21 & Kelas B \\
\hline 64 & 48 & 25 & Kelas B \\
\hline 66 & 48 & 22 & Kelas A \\
\hline 30 & 24 & 15 & Kelas A \\
\hline 35 & 28 & 18 & Kelas A \\
\hline 50 & 30 & 20 & \\
\hline
\end{tabular}

Tabel di atas (database vektor fitur citra pelatih) akan digunakan sebagai acuan menentukan citra Gula Merah yang akan diuji pada kelas mana Gula Merah yang akan diuji tersebut akan masuk, apakah kelas kualitas A, kelas kualitas B, atau kelas kualitas C.

Kemudian ada citra query yang belum diketahui label kelasnya dan ingin diketahui citra query tersebut masuk ke kelas kualitas A, B atau kelas C. Vektor fitur citra query tersebut:

red $=56$, green $=29$ dan blue $=20$.

Adapun prosedur perhitungan adalah sebagai berikut:

Menghitung jarak antara vektor fitur citra query dengan contoh database vektor fitur data Sampel menggunakan rumus euclidean distance. 
$\operatorname{Dist}(\mathrm{i}, \mathrm{k})=\sqrt{\sum_{i=j}^{D}\left(\tilde{l}_{j}-k_{j}\right)^{2}}$

Disederhanakan menjadi:

Dist $(\mathrm{i}, \mathrm{k})=\sqrt{\left(R_{\mathrm{i}}-R_{k}\right)^{2}+\left(G_{\mathrm{i}}-G_{\mathrm{k}}\right)^{2}+\left(B_{\mathrm{i}}-B_{k}\right)^{2}}$

Dengan:

i adalah vektor fitur dari database vektor fitur citra latih $\mathrm{k}$ adalah vektor fitur citra query

Tabel 3. Perhitungan Jarak Euclidean

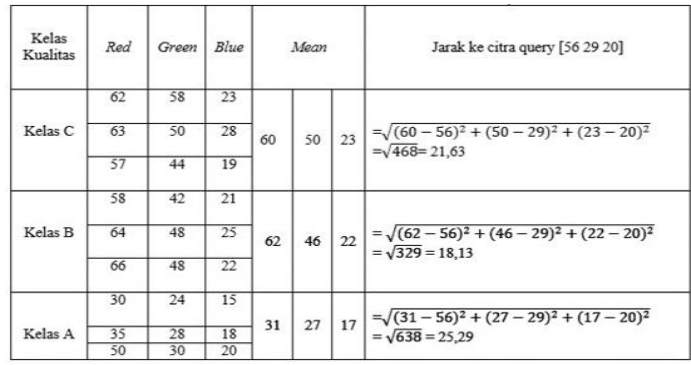

Selanjutnya mengumpulkan kelas klasifikasi.

\section{HASIL DAN PEMBAHASAN}

Setelah melakukan peneletian dengan mengambil beberapa data dan mengolahnya sesuai dengan sumber yang ada baik dari buku maupun observasi, maka hasil dari penelitian tersebut

terciptalah aplikasi Sistem Cerdas Berbasis Matlap, berikut adalah beberapa tampilan dari aplikasi tersebut.

a. Tampilan Menu Utama

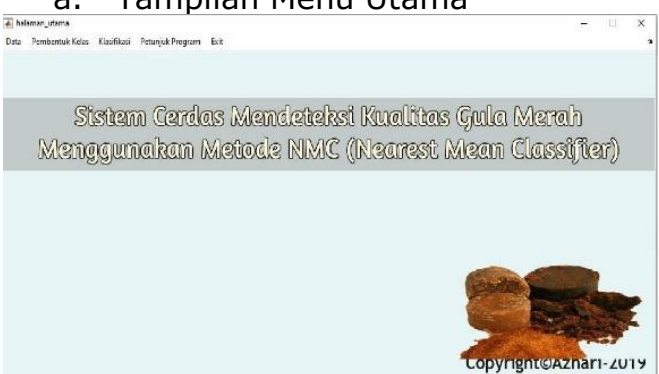

Gambar 1. Tampilan Menu Utama

Pada antar muka (gambar 3.1) di atas, terdapat pilihan menu (menu bar) yang dapat digunakan baik oleh developer, maupun oleh user/pengguna sistem. Menu Data, Menu Pembentukan Kelas, Menu Klasifikasi, Menu Tentang, dan Menu Keluar.

\section{b. Tampilan Antar Muka Klasifikasi}

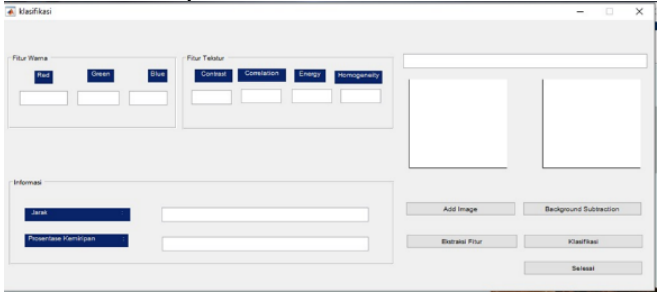

Gambar 2. Tampilan Antar Muka Klasifikasi
Pada antar muka klasifikasi di atas, terdapat suatu antar muka klasifikasi yang mana antar muka tersebut dibagai menjadi 2 panel, yakni panel fase pembentuk kelas dan panel fase klasifikasi. Panel fase pembentuk kelas ditujukan untuk membentuk kelas klasifikasi dalam rangka pelatihan sistem, sedangkan panel klasifikasi ditujukan untuk melakukan klasifikasi/pengenalan terhadap suatu data uji. Sebelum bisa dilakukan klasifikasi terhadap suatu data uji (citra query gula merah), terlebih dahulu harus dilakukan pembentukan kelas pada fase pembentuk kelas.

c. Tampilan Antar Muka Fase Pembentuk Kelas

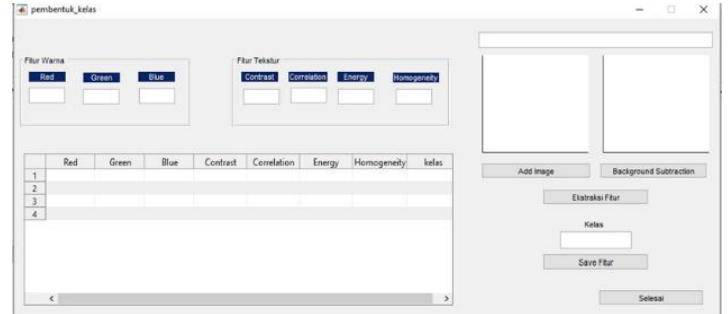

Gambar 3. Antar Muka Fase Pembentuk Kelas

Pada antar muka fase pembentuk kelas (gambar 4.4) di atas, pada panel yang berada disebelah kiri, yakni panel fase pembentuk kelas terdapat beberapa tombol yang dapat digunakan oleh developer untuk melakukan kegiatan pelatihan terhadap sistem dengan membentuk kelas-kelas klasifikasi menggunakan file citra latih. Adapun tomboltombol tersebut adalah sebagai berikut:

i. Tombol Add Image untuk memulai melakukan pelatihan kepada sistem dengan membaca file citra latih.

ii. Tombol Background Subtraction untuk memisahkan objek gula merah latih dari latarnya.

iii. Tombol Ekstraksi Fitur untuk melakukan proses ekstraksi fitur citra latih.

iv. Tombol Simpan Fitur untuk menyimpan vektor fitur citra latih hasil dari ekstraksi fitur ke dalam database vektor fitur citra latih.

v. Tombol Selesai untuk membersihkan area fase pembentuk kelas menandakan kegiatan pelatihan terhadap sistem telah selesai.

\section{KESIMPULAN DAN SARAN}

Identifikasi kualitas gula merah menggunakan fitur bentuk dan fitur warna yang mempunyai tingkat keberhasilan yang sangat baik. Semakin banyak sampel yang diberikan kepada sistem maka, kemampuan sistem akan semakin baik. Hasil percobaan 
yang dilakukan menunjukkan sistem yang dibuat ini dapat memberikan ketelitian sebesar $79.7 \%$ untuk 30 sampel data perkelas, diantaranya 10 sampel data gula merah sangat baik, 10 sampel gula merah baik, dan 10 sampel gula merah kurang baik.

\section{DAFTAR PUSTAKA}

[1] B. Rianto, "Perancangan Sistem Informasi Pemasaran Kerajinan Tangan Khas Inhil Berbasis Web," Riau J. Comput. Sci., vol. 4, no. 1, pp. 67-75, 2018.

[2] F. Hesty et al., "Rancang bangun aplikasi sistem cerdas penilaian kepemimpinan berdasarkan test papi kostick," J. Algoritm., vol. 1, pp. 122129, 2010.

[3] W. R. H. Nawansih, Samsul Rizal, "Survey Mutu dan Keamanan Gula Merah di Pasar Kota Bandar Lampung," Univ. Lampung Teknol. Pertan., pp. 1-15, 2011.

[4] A. Abdullah, U. Usman, and $M$. Efendi,"Sistem Klasifikasi Kualitas Kopra Berdasarkan Warna dan Tekstur Menggunakan Metode Nearest Mean Classifier (NMC)," J. Teknol. Inf. dan Ilmu Komput., vol. 4, no. 4, pp. 297304, 2017.

[5] R. Sovia and J. Febrio, "Membangun Aplikasi E-Library Menggunakan Html, Php Script, Dan Mysql Database," J.Teknol. Inf. Pendidik., vol. 6, no. 2, pp. 38-54, 2011.

[6] D. Sukrianto, "Penerapan Teknologi Barcode pada Pengolahan Data Pembayaran Sumbangan Pembinaan Pendidikan ( SPP )," Intra-Tech, vol. 1, no. 2, pp. 18-27, 2017.

[7] R. Afyenni, "Perancangan Data Flow Diagram Untuk Sistem Informasi Sekolah (Studi Kasus Pada SMA Pembangunan Laboratorium UNP)," Teknoif, vol. Vol. 2 No., no. 1, pp. 1-3, 2014.

[8] A. Sugiharto, Pemrograman GUI denganMatlab. 2006.

[9] Z. Azmi, "visualisasi data dengan menggunakan matriks laboratory," Ilm. Saintikom (Sains dan Komput., pp. 209-214, 2012.

[10] R. Sains, Penerapan Data Mining dengan Matlab. 2013.

[11] F. Ayu and N. Permatasari, "Perancangan Sistem Informasi Pengolahan Data Praktek Kerja
Lapangan (PKL) Pada Devisi Humas PT. Pegadaian," Intra-Tech, vol. 2, no. 2, pp. 12-26, 2018. 